\title{
Sağlık Hizmetleri Meslek Yüksekokulu Öğrencilerinin Uygulama Stajlarının Kalite ve Verimlilik Açısından Değerlendirilmesi*
}

Evaluation of Practice Internship of Health Vocational School Students in Terms of Quality and Productivity* $^{*}$

\author{
Melek KARATUZLA ${ }^{1}$ iD, Ebru BAĞÇI ${ }^{1}$
}

ÖZ

Uygulama stajlarının kalitesi, bireyin iş ve kariyer planlarını, yaşamla ilgili hedef ve amaçlarını doğrudan etkileyen bir faktör olarak karşımıza çıkmaktadır. Bu derlemede amaç Sağlık Hizmetleri Meslek Yüksekokulu öğrencilerinin uygulama stajlarının kalite ve verimlilik açısından incelenmesi ve sağlık sektörünün ihtiyacı doğrultusunda nitelikli ara elemanların yetiştirilmesinde uygulama eğitimlerinin etkisini araştırmaktır.

Amaçlanan hedef doğrultusunda staj eğitimi alan öğrenciler üzerinde yapılan 48 ulusal ve uluslararası akademik çalışmaya ulaşılmış ve bu çalışmalar bulgular açısından sistematize edilerek incelenmiştir. Mevcut çalışmalara DergiPark, EBSCOhost, MEDLINE, Scientific.Net, ULAKBİM-TR Dizin veri tabanları aracılığıyla ulaşılmış ve "kalite", "mesleki uygulama", "meslek yüksekokulu", "staj uygulamaları" anahtar kelimeleri girilerek taranmıştır.

Staj ve uygulamalı derslerin sürelerinin uzatılması, staj uygulamalarında denetimin artırılması, staj yeri yetkilisinin, stajyeri geleceğin meslek elemanı olarak görmesi, stajyere kendi iş alanlarına dair görevler verilmesi ile uygulama eğitimlerinin kalite ve veriminin artırılması gerektiği sonucuna ulaşılmış ve konuya ilişkin önerilerde bulunulmuştur.

Anahtar Kelimeler: Kalite, Verimlilik, Mesleki uygulama, Meslek Yüksekokulu, Staj.

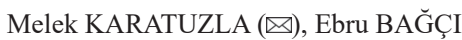

Beykent Üniversitesi Meslek Yüksekokulu, ISTANBUL

e-mail:melekkaratuzla@beykent.edu.tr

* Bu derleme 02.11.2019 tarihinde Beykent Üniversitesi, Hadımköy Yerleşkesinde düzenlenen 1. Ulusal Meslek Yüksekokullart Sempozyumu'nda sözlü bildiri olarak sunulmuştur.

\begin{abstract}
The quality of the practice internship is a factor that directly affects the individual's work and career plans, goals and objectives related to life. The aim of this review is to investigate the quality and efficiency of the practice internship of the students of vocational school of health services and to investigate the effect of application training in the training of qualified intermediate staff in line with the needs of the health sector.

In line with the aim, 48 national and international academic studies on students who have received training internship have been reached and these studies have been systematized in terms of findings. Existing studies have been reached through DergiPark, EBSCOhost, MEDLINE, Scientific.Net, ULAKBIM-TR Directory databases and "quality", "professional practice", "vocational school", "internship applications" were searched by entering the keywords.

As a conclusion, the duration of the internship and practical courses should be extended, the control of internship practices should be increased, the internship authority should consider the internship as the professional of the future, the internship should be given tasks related to their job areas, and the quality and efficiency of the training should be increased.
\end{abstract}

Keywords: Quality, Productivity, Vocational practice, Vocational School, Internship.

\section{GÍRISŞ}

Sağlık Hizmetleri Meslek Yüksekokulları 1983 yılında sağlık hizmetlerinde nitelikli ara eleman yetiştirmek amacıyla kurulmuş yükseköğretim kurumlarıdır. Meslek yüksekokulları 4 yarıyıl ve 2 yıllık eğitim ve öğretim süresi sonunda "Tekniker" ünvanıyla ülke çapında insan kaynağı yetiştirmektedir (1). Mezun edilen teknikerlerin kaliteli ve çalışkan olması, bilimsel ve teknolojik gelişmelere uyumlu, kaliteli hizmet sunan, ekip çalışmasına yatkın ve aynı zamanda mesleki becerileri gelişmiş orta düzey ara insan gücü olarak yetiştirilmesi, meslek yüksekokullarının hedefleri arasındadır (2). Bu amaçla öğrencilere verilen kaliteli eğitim, verilecek sağlık hizmetlerinin kalitesini 
olumlu yönde etkileyecektir. Verilen teorik ve mesleki eğitimin yeterliliği sağlık insan gücünün kalitesinin belirleyici unsurudur. Kaliteli ve verimli bir sağlık hizmeti yine kaliteli ve verimli bir sağlık eğitimine bağlıdır. Bununla beraber, ülkemizde sağlık sektöründe meydana gelen hızlı büyüme-gelişme ve sunulan sağlık hizmetinin bu hıza ayak uydurup doğru cevaplar verebilmesi yine nitelikli "Sağlık Ara İnsan Gücü (SAİG)" gereksinimini ön plana çıkarmaktadır $(3,4)$.

Türkiye'de 167 yükseköğretim kurumunda Sağlık Hizmetleri Meslek Yüksekokulu, Sağlık Bilimleri Meslek Yüksekokulu, Sağlık Meslek Yüksekokulu, Sağlık Astsubay Meslek Yüksekokulu adıyla Sağlık Bilimleri alanında eğitim veren meslek yüksekokulları ve bu meslek yüksekokullarında 41 farklı bölüm bulunmaktadır. Bu bölümlere; ambulans ve acil yardım teknikerliği, hemşirelik ve bakım hizmetleri, tıbbi hizmetler ve teknikler bölümleri örnek olarak verilebilir (5). Türkiye Yükseköğretim Yeterlilikler Çerçevesi'ne göre öğrencilerin almaları gereken ders yükü 120 AKTS'dir. 120 AKTS hem teorik hem de uygulamalı dersleri içermektedir. Uygulamalı derslere ilaveten yine temelinde uygulama olan ve bazı Meslek Yüksekokullarınca (MYO) zorunlu olan en az 30 iş günü mesleki çalışma alanlarında yapılan işyeri stajları, Meslek Yüksekokulu Programlarında mesleki gelişim adına önemli bir yer tutmaktadır (6).

Türkiye ile diğer ülkeler arasında ön lisans eğitimi açısından farklılıklar vardır. Örneğin Avustralya'da ön lisans eğitimi akademik odaklıdır ve hedef öğrencilere profesyonel meslek ve ileri öğrenim için gerekli temel becerileri kazandırmaktır. Bu eğitim sonunda mezunlardan beklenen problem çözme, karar verme ve analitik beceriler kazanmalarıdır. Programların eğitim süresi ise iki yıldır (7).

Amerika Birleşik Devletleri'nde ön lisans, birçok öğrencinin yükseköğrenim yolculuğunda attığı ilk adımdır. $\mathrm{Bu}$ eğitim programı iki yıllık bir çalışma gerektirir ve öğrencilere eğitimlerine devam etmeleri veya işgücüne girmeleri için ihtiyaç duydukları başlangıç eğitimi ve bilgilerini sağlar. Bu yüzden ön lisans derecesi, lisans ve diğer mesleklere giriş düzeyinde önkoşul olarak verilen bir eğitimdir. Sağlık Programları ise tamamlayıcı tıp, farmakoloji, fizyoterapi, danışmanlık fizyoloji gibi alanlarda eğitim vermektedir $(8,9)$

Almanya'da ise mesleki eğitim, Alman eğitim politikasının en önemli kısmıdır ve eğitimdeki yeri \%79 oranındadır. Mesleki eğitimler, eğitim ve işletme işbirliğini temel alır, bu sebeple ismi ikili sistem olarak anılmaktadır.
$\mathrm{Bu}$ sistemin kendine ait yapısı ve kuralları vardır. $\mathrm{Bu}$ eğitimde usta çırak ilişkisi modeli ön plandadır. Almanya'da üç ana mesleki eğitim alanı vardır $(10,11)$ :

- Mesleki eğitim ve öğretim

- Sürekli eğitim ve hizmet içi eğitim

- Mesleği değiş̧tirme

İngiltere'de ise genel eğitimler altıncı sınıf ve ortaokullarda; mesleki eğitimler ileri eğitim kolejlerinde verilmektedir. Orta öğretim düzeyinde verilen bu eğitimler sektörün ara eleman ihtiyacını karşılamada önemli bir rol oynamaktadır (12).

Avrupa Birliği ülkelerinde mesleki eğitim programlarının işgücü piyasasının ihtiyacına cevap vermek odaklı olduğu ve en önemlisi bu programların fen ve matematiğe dayandığı görülmektedir. Bu istihdam temelli eğitim programında istihdam sorununun çözülmüş olduğu ve mezunların mezuniyet sonrası hızlıca iş bulabildikleri ya da teknik alanlarda (mühendislik, fen vb.) eğitimlerine devam ettikleri görülmektedir (13).

Tüm eğitim kurumlarında olduğu gibi Sağlık Hizmetleri Meslek Yüksekokullarında da etkili eğitim ve kaliteli öğretim için; kurumun sahip olduğu, teknoloji, donanım ve imkânların genişliği gerekli unsurlardır; ancak mesleki gelişim adına uygun tesis ve kaynak sağlanması yeterli değildir $(6,14)$. Öğrencilerin 2 yıllık eğitimde edindikleri mesleki teorik bilgileri uygulamalar ve alan çalışmalarıyla desteklemeleri, beceri eğitimlerinin verilmesi ve iş hayatının sorumluluklarını, ekip üyesi olarak işbirliğinin ve iletişim süreçlerinin öğretilmesi gerekmektedir $(6,12,15,16)$. Öğrencilerin mesleki gelişimlerinin temelinde bulunan bu unsurlar, eğitim-öğretim süreci içerisinde iki farklı şekilde gerçekleştirilebilir; Bunlardan ilki, uygulamalı derslerle bilgi ve becerileri geliştirmek, ikincisi ise öğrencilerin mesleki iş alanlarındaki uygulama stajlarıdır $(6,11,14)$.

Meslek Yüksekokullarının eğitim plan ve programı içerisinde belirlenen staj takvimine uygun olmak koşuluyla, MYO işbirliği ile anlaşmalı kamu ve özel kurumlarda sağlanan stajlar, 2 yıllık eğitim ve öğretim sürecinin tamamlayıcı kısmıdır (17). Sağlık programı öğrencilerinin staj dönemleri ve süreleri bütün yükseköğretim kurumlarında aynı olmamakla beraber genellikle II. velveya IV. Dönem sonunda, kamu ve/veya özel sağlık kurum ve kuruluşlarda en az 30 iş günü olacak şekilde yaptırılmaktadır. Bu stajlar öğrencinin kayıtlı olduğu eğitim programının gerektirdiği 
bilgi ve teknolojiye sahip, aynı zamanda öğrencilerin 4 yarıyıllık dönemde kazanımlarını gerçek iş ortamında pekiştirebilecekleri, fiziki koşulları staj yapmaya elverişli kurumlarda yapilabilmektedir (1).

Uygulamalı derslerle edinilen mesleki bilgiler öğrenciler tarafindan becerilere dönüştürülerek uygulanması durumunda mesleki gelişim açısından verimli olacaktır. $\mathrm{Bu}$ yüzden Meslek Yüksekokul (MYO) Programlarında uygulamalı mesleki eğitimlerin kalitesinin artırılması nitelikli tekniker yetiştirmek adına oldukça önemlidir (18).

Meslek Yüksekokullarında verilen bu uygulamalı eğitimler teknikerlerin mesleki açıdan bilgi, beceri ve uygulama düzeylerini artırmanın yanı sıra hem niteliklerini, hem de problem çözme ve karar verebilme yeteneklerini de geliştirecektir. Aynı zamanda mesleklerini özümseyip, meslek adına bilimsel bilginin ne kadar gerekli olduğunun farkında olacaklar ve hayat boyu mesleki gelişmelerini sürdüreceklerdir. Bu bağlamda Sağlik Meslek Yüksekokullarında verilen nitelikli eğitimler hem mesleki gelişimi hem de sağlık teknikerinin bilgisayar kullanımı, yabancı dil öğrenimi gibi teknik ve sosyal gelişimlerini de sağlamalıdır $(1,19)$.

Öğrencilerin alanları ile ilgili çalışma ortamında aldıkları eğitim ve doğrudan hasta üzerinde yapılan eğitimler becerilerini geliştirmelerinin yanında aldıkları teorik bilgilerinin de kanıtlanması ve öğretilerin yerini bulabilmesi açısından da oldukça önemlidir. Ayrıca öğrenciler uygulamalı eğitimlerle birlikte gördükleri mesleki stajlarla da mesleğe karşı olumlu tutum ve davranış geliştirerek motivasyonlarını da artırmaktadır. Staj dönemlerini başarılı bir şekilde tamamlayan öğrenciler öğrendikleri bilgi ve edindikleri becerileri uygulayarak ve yaşayarak hayata geçirme şansı yakalamaktadırlar $(6,20)$.

Kaliteli ve verimli geçirilen uygulama stajları, mesleki bilgi ve becerilerin sağlanmasının yanı sıra, öğrencilerin iş hayatında önlerine çıkabilecek problemlere karşı tutumlarını belirlemelerine, ekip ve yöneticileri ile sağlıklı ve etkili iletişim kurmalarına firsat sunar. Aynı zamanda öğrenciler, hem okul hem de uygulama hayatını deneyimleyerek donanım ve özgüvenlerini geliştirir, iş hayatları açısından referans ve mesleki deneyim kazanırlar $(21,22)$.
Uygulama stajlarının kalite ve verimliliği, bireyin meslek ve kariyer planlarını; yaşamla ilgili hedef ve amaçlarını doğrudan etkileyen bir faktör olarak karşımıza çıkmaktadır. $\mathrm{Bu}$ derlemede amaç Sağlık alanında öğrenim veren MYO öğrencilerinin uygulama stajlarının kalite ve verimlilik açısından incelenmesi ve sağlık sektörünün ihtiyacı doğrultusunda nitelikli ara elemanların yetiştirilmesinde uygulama eğitimlerinin etkisini araştırmaktır.

\section{YÖNTEM}

Üniversite düzeyindeki meslek yüksekokullarında teorik derslerle birlikte ve sonrasında mesleki uygulama derslerine yer veriliyor olsa da staj; öğrencilerin iş hayatını deneyimlemeleri, uygulama ve teorik derslerde öğrendikleri bilgileri gerçek hasta ve yaralılar üzerinde uygulamaya dökme imkânı bulmaları açısından önem taşımaktadır. $\mathrm{Bu}$ bağlamda mesleki eğitim süresince öğrenciler için en etkili ve verimli yöntem, mesleki staj eğitimidir. Amaç doğrultusunda çalışmada literatür tarama yöntemi kullanılmıştır. Staj eğitimi alan Sağlık Hizmetleri Meslek Yüksekokulu ve Meslek Yüksekokulunun Sağlık Programı öğrencileri üzerinde yapılan, mesleki stajları konu edinen ve çalışmanın amaçları ile örtüşen 23 ulusal ve 26 uluslararası akademik çalışmaya ulaşılmış ve bu çalışmalar bulgular açısından derlenerek incelenmiştir. Mevcut çalışmalara DergiPark, EBSCOhost, MEDLINE, Scientific.Net, ULAKBİM-TR Dizin veri tabanları aracılığıyla ulaşılmış ve "kalite", "mesleki uygulama", "meslek yüksekokulu", "staj uygulamaları", "quality", "professional practice", "vocational school", "internship applications" anahtar kelimeleri girilerek taranmıştır.

\section{BULGULAR}

Ulusal literatürde yapılan çalışmalar ve derlemeler incelendiğinde, Sağlık MYO programı öğrencilerinin staj kalite ve verimini etkileyen kişisel problemlerinin yanı sıra, eğitim kurumu ve staj kurumlarıyla ilişkili problemlerinin araştırıldığı çalışmaların yapılmış olduğu ve bu çalışmalarda ortak problemlerin tespit edildiği görülmüştür. Yapılan bu çalışmalar 1şığında bazı önerilerde bulunulduğu gözlemlenmiştir (Tablo 1). 
Tablo 1. Ulusal literatürde staj ile ilgili çalışmalarda incelenen sorunlar ve çözüm önerileri

\begin{tabular}{|l|l|}
\hline SORUNLAR & ÇÖZÜM ÖNERILERİ \\
\hline $\begin{array}{l}\text { Staj süresinin yetersizliği } \\
(1,6,12,23-29)\end{array}$ & Staj süresi uzatılmalıdır (1,6,12,23-29) \\
\hline $\begin{array}{l}\text { Yeterli bilgi ve beceri } \\
\text { kazandırma isteksizliği } \\
(1,18,21,24,26,30)\end{array}$ & $\begin{array}{l}\text { Çalışanlar tarafından stajyere yeterli } \\
\text { bilgi ve beceri aktarımı olmalıdır } \\
(1,18,21,24,26,30)\end{array}$ \\
\hline $\begin{array}{l}\text { Denetimlerin olmamas1 } \\
(1,2,8,21,24,26,31)\end{array}$ & $\begin{array}{l}\text { Stajyer ara ara ilgili öğretim } \\
\text { elemanı tarafından denetlenmelidir } \\
(1,2,18,21,24,26,31)\end{array}$ \\
\hline $\begin{array}{l}\text { Stajyerlere geçici eleman } \\
\text { gözüyle bakılmas1 } \\
(2,3,21,24-26,30)\end{array}$ & $\begin{array}{l}\text { Stajyerlere geçici eleman gözüyle } \\
\text { bakılmamalı, geleceğin meslek üyesi } \\
\text { olarak değerlendirilmelidir }(2,3,21,24- \\
\text { 26,30) }\end{array}$ \\
\hline Güvensizlik (24-27,30) & $\begin{array}{l}\text { Öğrencilere öğrenim sürelerinde } \\
\text { edindikleri bilgi ve beceri doğrultusunda } \\
\text { sahada güven duyulmalı ve öğrenciler } \\
\text { cesaretlendirilmelidir (24-26,30) }\end{array}$ \\
\hline
\end{tabular}

İncelenen 48 ulusal ve uluslararası çalışmada stajın önemini, kalite ve verimliliğini etkileyen ortak bulgular ise şöyledir;

- Stajlar, öğrenciler için sektör ve kariyer planlamalarında önemli bir etkendir $(2,20,21,23,28-30,32-39)$.

- Öğrenciler sektörler arasında çalıştırılabilecek ucuz işgücü olarak görüldüklerinden, fazla çalıştırıldıklarından ve gereksiz işler yaptırıldığından yakınmaktadır $(2,3,6,17,18,24,25,36,40)$.

- Staj süreleri yetersizdir $(2,6,14,23,24,31,34,41,42)$.

- Staj uygulamalarının etkili ve verimli olabilmesi için alanında uzman öğretim elemanları tarafindan öğrencilerin denetlenmesi faydalı olabilir (1$3,14,17,18,21,24,27,31,32,34,36,37,40,41,43)$.

\section{TARTIŞMA}

Sağlık MYO bünyesindeki programlarda öğrenim gören öğrencilerin alanlarıly ilgili kamu ve özel kurum ve kuruluşlarda yaptıkları stajlar mesleki yeterlilik ve gelişim bakımından önemlidir. Staj sürecinde; öğrencilerin mesleklerini ve mesleki iş alanlarını tanımaları, edindikleri uygulama becerilerini arttırmaları gibi hedefler bulunmaktadır. Mesleki staj sürecinin bu hedeflere ulaşacak şekilde sürdürülmesi, stajyer öğrencilerin mesleki bilgi ve beceri kazanımlarını istenilen derecede yükseltilmesine bir basamak olacaktır. $\mathrm{Bu}$ süreçleri negatif etkileyen problemlerin tespit edilmesi ve sonrasında çözüm odaklı yaklaşımlar verimli ve kaliteli bir staj süreci için gereklidir. Staj süreçlerinden hedeflenen yetkinliklerin ulaşılamadığına dair araştırmaların varlığı, engel teşkil eden problemleri göz önüne sermiştir (23).

Tuygar'ın 2016 yılında yaptığı çalışmada staj sürelerinin uzatılmasının stajların daha etkin hale dönüştüreceği sonucuna ulaşılmıştır. Yine aynı çalışmaya göre stajyer öğrencilere meslek çalışanları tarafindan yeterli bilgi verilmemesinin nedenlerinin müdahale edilen durumların acil olması ve bilgi aktarımı süresinin müdahale açısından süre kaybına sebep olacağı endişesi, stajyerlere geçici eleman gözüyle bakıldığını ve stajyerlerin yeterince önemsenmediğini göstermektedir (24).

2015 yılında Mankan tarafından yapılan bir çalışmada ise, Meslek Yüksekokulları Sağlık Programlarında öğrenim gördükleri programları kendi istekleriyle seçen ve bölümüne ilgi duyan öğrencilerin staj uygulamalarını daha etkin ve verimli değerlendirdikleri görülmüştür (31).

Tunç ve Dal'ın 2018 yılında yaptığı çalışmaya göre ise öğrencilerin, "Stajların daha etkin hale getirilebilmesi için nasıl bir yöntem izlenmeli?" sorusuna verdiği cevaplar değerlendirilmiştir. Çalışmaya katılan öğrencilerin \% 21,9’u stajları daha etkin hale getirmek için staj yerinin uygun seçilmesi gerektiğini, vurgulamışlardır (2).

Henry, Rehwaldt ve Vineyard (2001), staj problemlerini tanımlayarak, staj programlarının nasıl verimli ve etkili bir şekilde gerçekleştirilebileceğini açıklamaya çalışmışlardır. Hem stajyer hem de araștırmacıların yer aldığı bu çalıșmada staj problemleri "çalışma yeri”, "çalışma saatleri", "yetersiz denetim", "çalışmanın önemi konusunda yetersiz bilgilendirme" ve "ücretler" olarak sınıflandırılmıştır. Farklı bir çalışmada, turizmle ilgili stajlarda benzer sorunların ortaya çıtığ 1 kaydedilmiştir (43-45). Bu durum Tablo 2'de verilen problemlerin dışında öğrenci, örgüt çalışanları ve ögretim elemanları arasında farklı problemlerin de varlığını göstermektedir. Geleceğin meslek adayları olan öğrencilerin mesleki tutumlarını ve kariyerlerini belirleyebilecek nitelikte olan stajlar, mesleğe bakış açısını etkileyerek sektörde çalışma planlarını değiştirebilmektedir $(6,46,47)$ (Tablo 2). Holdway ve arkadaşları hemşireler üzerinde yaptığ 1 çalışmada olumlu geçirilen staj sürelerinin hemşirelik mesleğine yönelik tutumları olumlu yönde etkilediği sonucuna varmıştır (49). Ayrıca konu ile ilgili yapılan benzeri çalışmalarda da staj problemlerinin stajyerlerin mesleğe karşı bakış açısını ve mesleği yapma niyetini etkilediğini göstermiştir $(22,46)$. Bu bağlamda 
mesleğe karşı tutumun mesleği yapma niyetini etkileyen önemli bir aracı olduğu söylenebilir (22).

Tablo 2. Uluslararası literatürde staj ile ilgili çalışmalarda incelenen sorunlar ve çözüm önerileri

\begin{tabular}{|l|l|}
\hline SORUNLAR & ÇÖZÜM ÖNERILERİ \\
\hline $\begin{array}{l}\text { Staj süresinin yetersizliği } \\
(31,34,41)\end{array}$ & Staj süresi uzatılmalıdır $(31,34,41)$ \\
\hline $\begin{array}{l}\text { Uygun olmayan ve kısıtlı } \\
\text { eğitim } \\
(31,33,36,37,41,48)\end{array}$ & $\begin{array}{l}\text { Staj yeri eğitim kurumu arasındaki işbirliği } \\
\text { artırılmalı ve gereksiz bilgiler yerine } \\
\text { detaylı ve mesleki bilgiler verilmelidir } \\
(31,33,36,37,41,48)\end{array}$ \\
\hline $\begin{array}{l}\text { Denetimlerin azlığı veya } \\
\text { olmaması } \\
(31,36,38,40,45)\end{array}$ & $\begin{array}{l}\text { Stajyer ara ara ilgili öğretim elemanı } \\
\text { tarafından denetlenmelidir }(31,36,38,40,45)\end{array}$ \\
\hline $\begin{array}{l}\text { Eğitimlerde isteksizlik } \\
(31,40,48)\end{array}$ & $\begin{array}{l}\text { Örgüt çalışanları stajyer yetiştirme } \\
\text { konusunda daha istekli davranmalıdır } \\
\text { (31,40,48) }\end{array}$ \\
\hline $\begin{array}{l}\text { Ucuz işgücü olarak } \\
\text { görülme ve güvensizlik } \\
(33,36,37,40,48)\end{array}$ & $\begin{array}{l}\text { Öğrencilere öğrenim sürelerinde } \\
\text { edindikleri bilgi ve beceri doğrultusunda } \\
\text { sahada güven duyulmalı ve öğrenciler } \\
\text { cesaretlendirilmelidir. } \\
\text { Öğrencilere alanlarıyla ilgili işlerde görevler } \\
\text { verilmelidir (33,36,37,40,48) }\end{array}$ \\
\hline
\end{tabular}

Belirli bir süre boyunca mesleki saha çalışmalarını yapan öğrenciler, örgüt yönetimi ve mesleki rol modelleri tarafindan geçici eleman ve ucuz iş gücü olarak görüldüklerini ve bu doğrultuda alan dışı işlerde de çalıştırıldıklarından yakınmaktadır. Dolayısıyla yöneticiler ve meslek çalışanları sebebiyle öğrencilerin, mesleğe karşı olumsuz tutum ve düşünceler üretmesine, bu da mesleki kariyer planlarının olumsuz etkilenmesine sebep olmaktadır. $\mathrm{Bu}$ yüzden mesleği sevme ve benimseme adına kaliteli ve verimli staj sürecinin önemi açığa çıkmaktadır $(33,36,37,40,48)$.

Tablo 1'e göre incelenen ulusal çalışmalarda öğrencilerin staj boyunca karşılaştıkları güçlükler incelenmiştir. $\mathrm{Bu}$ nedenle tespit edilen sorunların çözümünün sağlanması ile staj sürelerinin daha etkin ve verimli geçirileceği sonucuna ulaşılabilir.

\section{SONUÇ ve ÖNERİLER}

$\mathrm{Bu}$ çalışmada ön lisans düzeyinde eğitim veren Sağlık Hizmetleri Meslek Yüksekokulu öğrencilerinin zorunlu staj uygulamalarının kalite ve verimliliğini etkileyen sorunlar ve bu sorunların çözüm yolları araştırılmıştır. Bu bağlamda, Türkiye'nin ara eleman ihtiyacının Meslek Yüksekokulları aracılığıyla daha etkin karşılanabilmesi, uygulama eğitimlerinin daha etkin ve kaliteli olabilmesi sağlık bilimleri alanındaki Meslek Yüksekokullarında verilen uygulama eğitimlerinin, sektörle beraber ve sektörün ihtiyac1 doğrultusunda yeniden yapılandırılması daha uygun olacağı düşünülmektedir. Staj ve uygulamalı derslerin sürelerinin uzatılması, staj uygulamalarında denetimin artırılmas1, staj yeri yetkilisinin, stajyeri geleceğin meslek elemanı olarak görmesi ve stajyere kendi iş alanlarına dair görevler verilmesi ile uygulama eğitimlerinin kalite ve verimliliğinin arttırılmasında etkili olacağı sonucuna ulaşılmıştır.

Ulusal ve uluslararası çalışmalardan elde edilen bulgular ışığında şu önerilerde bulunulabilir;

- Öğrencilerin eğitim gördükleri alanlarda teorik derslere kıyasla laboratuvar uygulamaları artırılmalı ve mesleki alanda kullanacakları beceriler program doğrultusunda geliştirilmelidir.

- Staj süresince öğrencilerin özgüvenleri sağlanmalı ve karar verme noktasinda sik sik denetimleri sağlanmalıdır.

- Öğrencilerin sahada ihtiyaç duyduğu anda danışabileceği rol modelleri olmalıdır.

- Sağl1k teknikerliği ile ilgili verilen teorik ve uygulamalı eğitimler mesleki bazda güncellenmeli, staj süreleri artırılmalıdır.

- Öğrencilerin staj sürecinde sahada güveniliruygulamalar yapabilmeleri için bilgi açığı kapatılmalıdır.

- Kurum yönetimi ve çalışanlar öğrencinin geleceğin meslek üyesi olacağ düşüncesiyle eğitim konusunda yeterli desteği sağlamalıdır.

\section{KAYNAKLAR}

1. Hançer Aydemir D. Meslek Yüksekokulu Öğrencilerinin Yaz Stajı Uygulamasına Bakış1: Sağlık Hizmetleri Örneği. Türk Yaşam Bilimleri Dergisi. 2016; 1(1): 34-42.

2. Tunç Y, Dal M. Sağlık Hizmetleri Meslek Yüksekokulu Öğrencilerinin Yaz Stajı Hakkındaki Görüş ve Önerileri: Iğdır Üniversitesi Örneği. Social Science Studies. 2018; 6(3): 377-403.

3. Yenal S, Çelikli S. İlk Ve Acil Yardım Programı Son Sınıf Öğrencilerinin Klinik Uygulamalarda Ve Ambulans İstasyonlarında Karşılaştıkları Güçlükler. İnönü Üniversitesi Sağlık Hizmetleri Meslek Yüksek Okulu Dergisi. 2013; 1(2): 7-15. Retrieved from http://dergipark.org.tr/inonusaglik/ issue/22778/409978. 
4. Aytekin G. Meslek Yüksekokullarında Yeniden Yapılanma Ve Yönetim Modelleri: Komisyon 1. Ankara Sağlık Hizmetleri Dergisi. 2015;14(2): 17-20.

5. Yükseköğretim Bilgi Yönetim Sistemi. İstatistikler. https:// istatistik.yok.gov.tr/(Erişim Tarihi: 02.04.2020).

6. Yenal S, Gültekin T. Sağlık Hizmetleri Meslek Yüksekokulu Son Sınıf Öğrencilerinin Klinik Uygulamalarda Karşılaştıkları Güçlükler. İnönü Üniversitesi Sağlık Hizmetleri Meslek Yüksekokulu Dergisi. 2019; 7(1): 58-66. doi: doi.org/10.33715/inonusaglik.547551, 2019

7. Country Education Profiles Australia. Pdf dökümanı. https:// internationaleducation.gov.au/Documents/ED15-0091_ INT_Australia_Country_Education_Profile_2015_ACC.pdf (Erişim Tarihi: 16.04.2020).

8. Amerika'da 152 Önlisans Dereceleri veya Hemşirelik Üniversite ve Bölümler. https://www.hotcourses-turkey.com (Erişim Tarihi: 10.10.2019)

9. Amerikan Eğitim Sistemi. (www.studyusa.com/tr/a/374/ amerikan-egitim-sistemi) (Erişim Tarihi: 09.10.2019)

10. Ato, Karşılaştırmalı Mesleki Eğitim Sistemi AlmanyaTürkiye, Eğitim ve Mesleki Yeterlilikler Özel İhtisas Komisyonu, Mart 2017, Ankara Ticaret Odas1, Ankara

11. Kazu Y, Özdemir O. Meslek Yüksekokulu Öğrencilerinin Beklentileri (Beklenti Profili): Frrat Üniversitesi Örneği. XIII. Ulusal Eğitim Bilimleri Kurultayı. 6-9 Temmuz 2004 İnönü Üniversitesi. Eğitim Fakültesi. 2004; Malatya

12. Karacaoğlu ÖC, Çabuk B. İngiltere ve Türkiye Eğitim Sistemlerinin Karşılaştırılması. Milli Eğitim Dergisi. 2002; 1(2): 155-56.

13. Associate Degree in Science for Health Professions-Delaware County Community College (DCCC). (www.educations. com/study-abroad/delaware-county-community-college/ associate-degree-in-science-for-health-professions-598509) (Erişim Tarihi: 10.10.2019)

14. Emir O, Arslan S, Kılıçkaya Ş. Turizm İşletmeciliği Programı Öğrencilerinin Staj Uygulamaları Hakkındaki Görüşlerinin Değerlendirilmesi: Afyon Kocatepe Üniversitesi Örneği. Afyon Kocatepe Üniversitesi İ̈BF Dergisi. 2008; 10(2):27391.

15. Acar Çiftçi Y. Çocuk Gelişimi Ön Lisans Programı Öğrencilerinin Staj Çalışmalarının İşlevselliği Üzerine Bir İnceleme. III. International Eurasian Educational Research Congress sunulan bildiri. Muğla S1tkı Koçman Üniversitesi, Muğla; 2016:1438-1439.

16. Beebe A, Blaylock A, Sweetser K. D. Job Satisfaction İn Public Relations İnternship. Public Relations Rewiev. 2009; 35: 156-158.

17. Tektaş N, Yayla A, Sarıkaş A, Polat Z, Tektaş M, Öz Ceviz N. Ön Lisans Öğrencilerinin Staj Uygulamalarının Değerlendirilmesi: Marmara Üniversitesi Örneği. Eğitim ve Öğretim Araştırmaları Dergisi. 2016; 5(Özel Sayı). Makale No: 36: 310-318. ISSN: 2146-9199.

18. Kaysi F, Aydemir E. Meslek Yüksekokulu Öğrencilerinin Stajlarda Karşılaştıkları Sorunların Değerlendirilmesi. Trakya Üniversitesi Sosyal Bilimler Dergisi. 2018; 20(2): 119-33. DOI: 10.26468/trakyasobed.427663, 2018.
19. Güldaş N, Kutluk D, Ergör A. Sağlık Sektörününün Tıbbi Laboratuvar Teknikerinden Beklentileri. DEÜ Tıp Fakültesi Dergisi. 2010; 24(2): 45-55.

20. Schambach TP, Dirks J. Student Perceptions Of Internship Experiences. Proceedings of the $17 \mathrm{~h}$ Annual Conference of the International Academyfor Information Management. 2002; 1-8.

21. Dolmacı N, Duran Y. Ön Lisans Düzeyinde Öğrenim Gören Öğrencilerin Zorunlu Staj Uygulamasına İlişkin Görüşleri, Sorunları Ve Çözüm Önerileri: Isparta Meslek Yüksekokulu Örneği. Mehmet Akif Ersoy Üniversitesi Sosyal Bilimler Enstitüsü Dergisi. 2017; 9(21): 254-267.

22. Aytekin G, Turan Özdemir S, Ediz P, Ceylan F. Sağlık Hizmetleri Meslek Yüksekokullarında Verilen Eğitimle İlgili Sorunlar, Çözüm Önerileri, Uludağ Üniversitesi Sağlık Hizmetleri Meslek Yüksekokulundaki Durum ve Yürütülen Çalışmalar. Ankara Sağlık Hizmetleri Dergisi. 2015; 14(1): $1-5$.

23. Morkoç D, Doğan M. Meslek Yüksekokulu Mezunu Çalışanların Mesleki Eğitime Yönelik Görüşleri: Çanakkale Onsekiz Mart Üniversitesi Örneği. Ejovoc (Electronic Journal Of Vocational Colleges). 2014; 4(4): 112-121.

24. Tuygar ŞF. Paramedik Programı Öğrencilerinin Yaz Staj1 Hakkındaki Görüşlerinin İncelenmesi. Düzce Üniversitesi Sağl1k Bilimleri Enstitüsü Dergisi. 2016; 6(2): 92-100.

25. Demirağ H, Hintistan S. İlk ve Acil Yardım Programı Öğrencilerinin Yaz Stajı Hakkındaki Görüşlerinin İncelenmesi. Ordu Üniversitesi Hemşirelik Çalışmaları Dergisi. 2019; 2(1): 46-55.

26. Karacan S, Karacan E. Meslek Yüksekokullarında (MYO) Yapılan Staj Uygulamalarına İlişkin Bir Araştırma: Kalite ve Verimlilik İçin İş Yerleri-MYO İşbirliğinin Gereği. Kocaeli Üniversitesi Sosyal Bilimler Dergisi. 2004; 8: 168-184.

27. Eskimez Z, Alparslan N, Öztunç G, Torun S. Hemşirelerin Adana Sağl1k Yüksekokulu Öğrencileri Ve Öğretim Elemanlarının Klinik Uygulamalarına İlişsin Görüşleri. Anadolu Hemşirelik Ve Sağlık Bilimleri Dergisi. 2005; 8(3): 30-39.

28. Gürdoğan A, Atabey S. Öğrencilerin Meslek Stajından Memnuniyet Düzeylerinin Kariyer Hedeflerine Etkisi. Muğla Sitkı Koçman Üniversitesi İktisadi Ve İdari Bilimler Fakültesi Ekonomi Ve Yönetim Araştırmaları Dergisi. 2015; 4(1): 91-113.

29. Kılıç Y, Yılmaz E. Meslek Yüksekokulu Öğrencilerinin Perspektifinden Mesleki Eğitime İlişkin Bir Durum Çalışması. Academia Eğitim Araştırmaları Dergisi. 2018; 3(1): 1-16.

30. Göllüce A, Avan H, Karsu F. Öğrenci Gözüyle Paramedik Mesleği. Hastane Öncesi Dergisi. 2017; 2(1): 1-9.

31. Akomaning E, Voogt JM, Pieters JM. Internship İn Vocational Education And Training: Stakeholders' Perceptions Of İts Organisation. Journal of Vocational Education \& Training. 2011; 63(4): 575-592.

32. Velde C, Cooper T. Students' Perspectives Of Workplace Learning And Training İn Vocational Education. Education and Training. 2000; 42(2): 83-92. DOI: 10.1108 / 004.009.10010331639, 2000. 
33. Ross LE, Elechi OO. Student Attitudes Towards İnternship Experiences: From Theory To Practice. Journal of Criminal Justice Education. 2002; 13 (2): 297-312.

34. Kaşlı M, İlban MO. The Relationship Between Problems Faced During İnternships And İnterns' View Of Profession And İntention To Work İn The Tourism İndustry. Egitim Arastirmalari-Eurasian Journal of Educational Research. 2013; 52: 79-96.

35. Mankan E. Mesleki Ön lisans Proğramlarında Staj Eğitiminin Önemi: Bülent Ecevit Üniversitesi Çaycuma Meslek Yüksekokulu Örneği. Akademik sosyal Araştırmalar Dergisi. 2015; 3: 734-741.

36. Rothman M. Lessons Learned: Advice To Employers From İnterns. Journal Of Education For Business. 2007; 82(3): 140-144.

37. Satariano WA, Rogers SJ. Undergraduate İnternships: Problems And Prospect, Teaching Sociology. 1979;4(4): 355-372.

38. Hannon FB. A National Medical Education Needs' Assessment Of İnterns And The Development Of An İntern Education And Training Programme. Medical Education. 2000; 34(4): 275-284.

39. Ulus L, Tuncer N, Sözen Ş. Mesleki Eğitim, Gelişim Ve Yeterlilik Açısından Meslek Yüksekokullarının Önemi. Uluslararası Türk Eğitim Bilimleri Dergisi. 2015; (5): 16885 .

40. Holmboe ES. Faculty And The Observation Of Trainees' Clinical Skills: Problems And Opportunities. Academic Medicine. 2004; 79(1): 16-22.

41. Parveen S, Mirza N. Internship Program İn Education: Effectiveness, Problems And Prospects. International Journal of Learning \& Development. 2012; 2(1): 487-498.
42. Gökdoğan O, Sarıgöz O, Meslek Yüksekokulu Öğrencilerinin 'Mesleki Uygulama Dersi'ile İlgili Görüşlerinin Değerlendirilmesi. Batman Üniversitesi Yaşam Bilimleri Dergisi. 2012; 1(1): 1091-1100.

43. Henry JS, Rehwaldt SS, Vineyard GM. Congruency Between Student İnterns And Worksite Supervisors Regarding Critical Elements Of An İnternship Experience (Electronic Version). Information Technology, Learning, And Performance Journal. 2001; 19(1): 31-41.

44. Busby GD, Gibson P. Tourism And Hospitality İnternship Experiences Overseas: A British Perspective. Journal of Hospitality, Leisure, Sport and Tourism Education. 2010; 9(1): 4-12. doi:10.3794/johlste.91.244, 2010.

45. Atabay S, Akın N. Avrupa Birliği Ülkeleri Eğitim Politikaları, Talim ve Terbiye Kurulu Başkanlığı Avrupa Birliği Masası. Ankara: Milli Eğitim Basımevi, 1996.

46. Karaman A, Metin AE, Güven Ş. Ormancılık ve Orman Ürünleri Programını Tercih Eden Öğrencilerin Gerekçelerinin ve Kariyer Planlarının Araştırılması: Uşak Üniversitesi Örneği. Itobiad: Journal of the Human \& Social Science Researches. 2017; 6(2).

47. Tekbalkan M, Sevim B. Meslek Yüksekokulu Mezunlarının Program Bazında Kamuda İstihdamı: 2015 Yılı Örneği. Organizing Committee Members. 2016; 739.

48. Glynn P, Silva S. Meeting The Needs Of New Graduates İn The Emergency Department: A Qualitative Study Evaluating A New Graduate İnternship Program, Journal of Emergency Nursing. 2013; 39(2): 173-178.

49. Holdway K, Corbeil S, McPherson CJ, Oremush S, Murray MA. Creating A Bridge Between Academic And Clinical Realities For Student Nurses: Evaluation Of A Summer Student İnternship Program. Nursing Leadership. 2005; 18.1: $1-7$. 